FACTA UNIVERSITATIS

Series: Physical Education and Sport Vol. 16, N 1, 2018, pp. 221 - 228

https://doi.org/10.22190/FUPES170626020S

Research article

\title{
THE EFFECTS OF AN EXERCISE PROGRAM ON THE BALANCE OF YOUNG PEOPLE WITH INTELLECTUAL DISABILITIES
}

\author{
UDC 796.01-056.24
}

\section{Marija Stojanović, Marko Aleksandrović, Aleksandra Aleksić-Veljković}

Faculty of Sport and Physical Education, University of Niš

\begin{abstract}
The aim of this study was to determine the effects of the 12 weeks experimental exercise program on the balance of adolescents with mild intellectual disabilities. Participants were 15 adolescents aged 15-20 years (18.18 \pm 1.54 years) with mild disturbances in intellectual functioning attending a special school ",October 14th" in Nis. The program consisted of games with the balls and polygons on the basketball court. The balance ability was tested by nine tasks of the BOT-2 (Bruininks-Oseretsky Test of Motor Proficiency). The results indicate that the applied exercise program contributed to the statistically significant increase in total score of balance $(p=.002)$, walking foreward heel-toe on the line $(p=.045)$, standing on one leg on a line with eyes closed $(p=.027)$ and standing on one leg on balance beam with eyes closed $(p=.006)$. The applied exercise program had a positive influence on the balance of young people with mild intellectual disabilities. Additionally, the results can provide useful information in optimizing the training loads of students with mild intellectual disabilities throughout Physical Education classes.
\end{abstract}

Key words: Bruininks-Oseretsky Test, Motor Proficiency, Physical Education

\section{INTRODUCTION}

Intellectual disability is characterized by significant limitation in intellectual functioning and adaptive behavior, as reflected in conceptual, social and practical adaptive skills. The disorder usually occurs before the age of 18 (Buntinx \& Schalock, 2010). Etiology of mild intellectual disability usually presents a combination of negative environmental conditions together with genetic, neurological and metabolic factors. Children with intellectual disabilities are known to have an increased risk of mental health and behavioral problems

Received June 26, 2017 / Accepted March 30, 2018

Corresponding author: Aleksandra Aleksić Veljković

Faculty of Sport and Physical Education, University of Niš, St. Čarnojevića 10a, 18000 Niš, Serbia

Phone: +381 18510 900• E-mail: aleksic.veljkovic@ gmail.com 
compared to those of a similar chronological age without a developmental disability. In addition, they are at risk of having a range of physical disabilities, sensory difficulties, and psycho-social problems (Bernard, 2011). Individuals with intellectual disability need systematic intervention strategies for building their physical fitness (Karinharju, 2005).

Children with mild disabilities in intellectual functioning are at least different from children with typical development in their physical and motor characteristics. Although many children with this type of disorders showed deficits in motor development, these defects are rather associated with limited attention and misunderstanding than with functional deficits or motor control. Generally, the more severe intellectual disability causes the greater deficit in the development of motor skills (Winnick, \& Porretta, 2016).

People with mild intellectual disabilities have good social skills and may become independent or need little support in life (Maina, Albert, Bad, \& Bogetto, 2001) and they can participate in different physical activities in order to provide necessary abilities to function in everyday life. The essential components of motor behavior in children with intellectual disabilities are static and explosive muscular strength, balance, endurance in strength, general physical coordination, cardiorespiratory endurance, hand-eye coordination, manual dexterity, flexibility, speed and coordination of large extremity movements (Winnick, \& Porretta, 2016). Balance involves coordination and control, which is essential in everyday life, and should be understood not only as the ability to maintain position, but rather as the ability to quickly return to a stable position after disturbances (Kostic, 1999). There is a correlation between the degree of intellectual disability and balance (Vuijk, Hartman, Scherder, \& Visscher, 2010). Children with border intellectual disabilities had higher scores on balance tasks in relation to children with mild intellectual disabilities (Golubovic, Maksimovic, Golubovic, \& Glumbic, 2012).

Although numerous authors investigated the influence of different exercise programs on the balance of intellectually disabled children and adolescents (Giagazoglou, Arabatzi, Dipla, Liga, \& Kellis, 2012; Golubovic et al., 2012; Jankovic-Szymanski, Mikolajczyk \& Wojtanowski, 2012; Giagazoglou, Kokaridas, Sidiropoulou, Patsiaouras, Karra, \& Neofotistou, 2013), there is a need to provide more information and new programs in order to improve this ability, which is necessary for functioning. Earlier findings suggest that children with ID have lower scores on balance tasks (Stankovic, Aleksandrovic, AleksicVeljkovic, 2013) compared to typically developed peers, so it is necessary to provide useful information in optimizing the training loads of students with mild intellectual disabilities throughout Physical Education classes. The aim of the present study is to determine the effects of a 12-week experimental exercise program on the balance of adolescents with mild intellectual disabilities.

\section{METHODS}

\section{Participants}

The participants comprised a total of 15 high school students (mean age 18.18 \pm 1.54 years, height $170.53 \pm 10.24 \mathrm{~cm}$, weight $77.07 \pm 18.75 \mathrm{~kg}$ ) from " 14 October" school in Nis. The institutional review board of the University of Niš approved the procedures used in this study, and all of the participants and their parents or guardians gave their written informed consent before participation. The school psychologist recommended a list of 
students who should be involved in the study, in order to balance the sample based on the level of intellectual disability, which was characterized as mild.

\section{The experimental program}

The research contained pedagogical, explorative and scientific methods of using a specially designed 12-week experimental exercise program in the development of specific motor skills among intellectually disabled adolescents. The experimental exercise program had a frequency of two times a week, so the total number of classes was 24 . This exercise program was conducted at the sports hall of special school "14 October" in Nis. Each class lasted 45 minutes and comprised three parts: an introductory part - 10 minutes, main part - 30 minutes and the final part - 5 minutes.

The introductory part of the class was used for a warm-up through shaping exercises and figuratively running, during the main part different types of exercises was used, and the final part was designed for breathing exercises and relaxation.

The main part of the class content is always selected based on the current mood and emotional state of the students, considering that this is a very sensitive population (adolescents with intellectual disabilities). Polygons and tasks with balls have always been readily accepted.

Different ball games were used during these classes (with tennis balls, volleyball balls, basketballs) which consisted of the different ways of throwing and catching, in order to avoid monotony. A leading role in the choice of content was played by the physical education teacher.

Polygons were performed on one half or the entire basketball court. The main tool in all the polygons were basketballs. Each polygon included different ways of moving: walking, fast walking, running at a slower and faster pace, usually while handling a ball. Very often the participants were asked to change the direction of movement. Basketball technique elements implemented as tasks in the polygons are:

- Dribbling more than three times (ball handling);

- Free guidance (control) of the ball in a stationary position and while moving;

- Keep the ball moving (with the dominant, subdominant hand or both hands alternately);

- Controlling the ball without looking at it (in a stationary position and while moving);

- Shooting a target on the wall (the target is a red circle on a white A4-size paper at shoulder height);

- Shooting at the basket for two or three points.

Exercises for strength were applied at the main part of classes, too:

- Climbing over the Swedish ladders;

- Sit-ups;

- V-ups (back extension);

- Push-ups on Swedish ladders. 


\section{Measures}

Balance status was determined by nine tasks of sub-test Balance from the BruininksOseretsky Test of Motor Proficiency, Second Edition (BOT-2, a battery of tests for assessing basic and fine motor skills development). It is used for identifying a person with a mild to moderate motor coordination deficit. It is applicable to the age range of 4-21 years (Bruininks \& Bruininks, 2010).

The balance subtest evaluates motor control skills that are associated with proper posture in a standing position, in walking and in other daily activities. These sub-test tasks assess three different aspects of balance manifestation: trunk stability, static and dynamic balance and the use of visual signals.

The tasks were: standing with feet apart on a line - eyes open, walking forward on a line, standing on one leg on a line - eyes open, standing with feet apart on a line - eyes closed, walking forward heel-to-toe on a line, standing on one leg on a line - eyes closed, standing on one leg on a balance beam - eyes open, standing heel-to-toe on a balance beam, standing on one leg on a balance beam - eyes closed (Bruininks \& Bruininks, 2010).

Measurements were made in the sports hall of special school "14 October" in Nis.

Measuring was conducted in accordance with the standards of the 2008 Helsinki Declaration on the Ethical Principles for Medical Research Involving Human Subjects (WMA, 2011).

\section{Statistical analyses}

The obtained data were analyzed using the statistical package SPSS 20.0. For all the variables obtained during the study, arithmetic means (Mean) and standard deviation (SD) were calculated. Due to the small sample size, the Kolmogorov-Smirnov Test (with the significance level set at $\mathrm{p}<.01$ ) was used to assess the normality of data distribution. To determine the difference between initial and final measurements, we used the t-test for dependent samples (Pallant, 2011). The level of significance up to .05 ( $\mathrm{p}<.05)$ was accepted as statistical significance for differences in the results of the variables between the two measurements.

\section{RESULTS}

The results of the descriptive statistical analysis for the variables obtained on the balance tests for initial and final measurements are presented in Table 1 and 2, respectively. Based on the results for the means, we find that the participants had better results at the final measurements compared to the initial measurements, except for the variable SOLBO (Standing on One Leg on a Balance Beam-Eyes Open).

The results for the Kolmogorov-Smirnov test indicated that most variables have a normal distribution. For the variables TOTINI (Total score on initial measurement) and SOLBCI (Standing on One Leg on Balance Beam - Eyes close) normal distribution was not established.

Table 3 presents the results of the t-test for dependent samples between the initial and final measurements.

The results from the last table indicate that there are statistically significant differences between the initial and final measurements for the variables: WFHTLI- WFHTLF, SOLLCISOLLCF, SOLBCI- SOLBCF and TOTINI- TOTFIN at the $\mathrm{p} \leq .05$ level of significance. 
Table 1 Descriptive statistics for balance variables at the initial measurement

\begin{tabular}{lrrc}
\hline Variables & \multicolumn{1}{c}{ Mean } & \multicolumn{1}{c}{ SD } & \multicolumn{1}{c}{ K-S $(\mathrm{p})$} \\
\hline SFALOI & 3.87 & .516 & .000 \\
SOLLOI & 3.47 & .990 & .000 \\
SFALCI & 3.20 & 1.146 & .000 \\
WFHTLI & 3.333 & 1.175 & .000 \\
SOLLCI & 2.467 & .743 & .005 \\
SOLBOI & 3.600 & 1.056 & .000 \\
SHTBOI & 3.800 & .561 & .000 \\
SOLBCI & 2.000 & 1.069 & .200 \\
TOTINI & 29.600 & 4.808 & .110 \\
\hline
\end{tabular}

Note: WFLI (Walking Forward on a Line Initial) is constant. It has been omitted.

Legend: SFALOI- Standing with Feet Apart on a Line- Eyes Open Initial, SOLLOI- Standing on One Leg on a Line-Eyes Open Initial, SFALCI- Standing with Feet Apart on a Line- Eyes Closed Initial, WFHTLI- Walking Forward Heel-to-Toe on a Line Initial, SOLLCI- Standing on One Leg on a Line- Eyes Close Initial, SOLBOIStanding on One Leg on a Balance Beam- Eyes Open Initial, SHTBOI- Sanding Heel-to-Toe on a Balance Beam Initial, SOLBCI- Standing on One Leg on a Balance- Eyes Close Initial, TOTINI- Total Initial score, Mean- arithmetic mean, SD- standard deviation, R- range, Min- the lowest result, Max- the highest result, K-S (p)-Kolmogorov-Smirnov Test (significance $\mathrm{p}<0.01$ ).

Table 2 Descriptive statistics for balance variables at the final measurement

\begin{tabular}{lrrc}
\hline Variables & Mean & \multicolumn{1}{c}{ SD } & K-S (p) \\
\hline SOLLOF & 3.867 & .352 & .000 \\
SFALCF & 3.667 & .488 & .000 \\
SOLLSF & 3.000 & 1.134 & .003 \\
SOLBOF & 3.467 & 1.125 & .000 \\
SOLBCF & 3.200 & 1.612 & .001 \\
TOTFIN & 33.200 & 3.858 & .000 \\
\hline
\end{tabular}

Note: WFLF (Walking Forward on a Line Final), SFALOF (Standing with Feet Apart on a Line- Eyes Open Final), WFHTLF (Walking Forward Heel-to-Toe on a Line Final) and SHTBOF (Sanding Heel-to-Toe on a Balance Beam Final) are constant. They have been omitted.

Legend: SOLLOF- Standing on One Leg on a Line-Eyes Open Final, SFALCF- Standing with Feet Apart on a Line- Eyes Closed Final, SOLLCF- Standing on One Leg on a Line- Eyes Close Final, SOLBOF- Standing on One Leg on a Balance Beam- Eyes Open Final, SOLBCF- Standing on One Leg on a Balance Beam- Eyes Close Final, TOTFIN- Total Final score, Mean- arithmetic mean, SD- standard deviation, R- range, Min- the lowest result, Max- the highest result, K-S (p)- Kolmogorov-Smirnov Test (significance $\mathrm{p}<0.01$ )

Table 3 The difference in the results for balance variables between the initial and final measurements (dependent t-test)

\begin{tabular}{lrcc}
\hline Variables & \multicolumn{1}{c}{$\mathrm{T}$} & $\mathrm{df}$ & $\mathrm{p}$ \\
\hline SFALO & -1.000 & 14 & .334 \\
SOLLOI- SOLLOF & -1.382 & 14 & .189 \\
SFALCI- SFALCF & -1.705 & 14 & .110 \\
WFHTLI- WFHTLF & -2.197 & 14 & $.045^{*}$ \\
SOLLCI- SOLLCF & -2.477 & 14 & $.027^{*}$ \\
SOLBOI- SOLBOF & .414 & 14 & .685 \\
SHTBOI- SHTBOF & -1.382 & 14 & .189 \\
SOLBCI- SOLBCF & -3.263 & 14 & $.006^{*}$ \\
TOTINI- TOTFIN & -3.893 & 14 & $.002^{*}$ \\
\hline
\end{tabular}




\section{DISCUSSION}

Children with disabilities learn in different ways; therefore, is not easy to find the best methods. Some children are very skilled at finding connections between objects and events, and others are prone to observing, and for this reason the role of the physical education teacher who works with these children is invaluable. Modern medicine cannot cure intellectual disability; however, there is a chance to improve the quality of life of people with this type of disability by means of physical exercises and by enhancing coordination, the quality of gait and efficiency in performing everyday activities (Jankowicz-Szymanska, Mikolajczyk, \& Wojtanowski, 2012). Scientists are increasingly concerned with examining the effects of different types of experimental exercise programs on the motor skills of children and adolescents with ID in order to provide information to those teachers.

Balance is very often examined, as one of the basic motor skills (required for each position and movement), but earlier results of research indicated a very poor state of balance in both genders of adolescents with ID (Stankovic, et al., 2013). The T-test for independent samples showed no statistically significant difference in the balance between boys and girls with mild impairments in intellectual functioning in the group of this age $(\mathrm{t}$ $=.039, \mathrm{df}=24, \mathrm{p}=.75$ ). According to BOT-2 descriptive criteria, the results in percentages are: The average value $26.9 \%$, Below-average value $38.5 \%$, Well-below average value $34.6 \%$. Blomqvist, Wester, \& Rehn (2014) found that adolescents with ID had significantly lower scores in the balance and muscle performance tests, too. The main aim of our investigation was to improve balance with a specially design program with optimal performance and impact on balance ability.

Similar to our exercise program, Radenkovic, Beric, \& Kocic (2014) suggest that basketball elements have a positive impact on motor skills and abilities in adolescents with mild ID, among them balance. The participants were precisely adolescents aged 1619 years who attend a special school. In the present study, after following a 12 -week experimental exercise program, a statistically significant increase was perceived in Total Score of Balance $(\mathrm{p}=.002)$. Looking at the results of the individual tests, it can be seen that there was statistically significant increase in: Walking Forward Heel-to-Toe on a Line $(\mathrm{p}=.045)$, Standing on One Leg on a Line- Eyes Close $(\mathrm{p}=.027)$ and Standing on One Leg on a Balance Beam - Eyes Close $(\mathrm{p}=.006)$. Only the result of Standing on One Leg on a Balance Beam - Eyes Open test had a lower value at the final than at the initial measurement $(3.47 \pm 1.13$ and $3.60 \pm 1.06)$. Such a result can be a consequence of lack of concentration when performing a task, and that opened eyes were disturbing, not a mitigating factor, since the measurements are not performed with each participant individually, it was attended by the whole class (Radenković, Berić, \& Kocić, 2014).

The other researchers studied changes in the balance of children and adolescents with mild (Golubovic et al., 2012; Jankowicz-Szymanska et al., 2012; Top, 2015) to moderate intellectual disabilities (Giagazoglou et al., 2012; Giagazoglou et al., 2013) under the influence of various intervention programs, too. The results similar to the present study were achieved JankowiczSzymanska et al. (2012) and the Top (2015). Considerable differences were noted in the tests with eyes closed $(\mathrm{p}=.042)$, under the influence of a 12-week exercise program in adolescents with Down's syndrome (as a cause of mild intellectual disability). The experimental program was applied twice a week, 45 minutes min for each training session, consisting of exercises on 
rehabilitation balls and air pillows, exercises in balance positions, standing and walking on surfaces with different structures and degrees of stability (Jankowicz-Szymanska et al., 2012). A swimming exercise program based on the Special Olympics Swimming Guide (60 minutes $/ 3$ days $/ 10$ weeks) also proved to be effective in terms of a positive impact on balance $(\mathrm{p}=.021)$ in adolescents with mild difficulties in intellectual functioning (Top, 2015). There was a statistically significant difference in the results of the balance test after an experimental fitness program $(\mathrm{p}=.000)$ in children with mild to borderline intellectual disabilities. The intervention program lasted 6 months, 3 times a week, each session 45 minutes. There was no statistically significant difference in the results of the balance test in the experimental group after the experimental exercise depending on the level of intellectual disability ( $\mathrm{p}=.307)$ (Golubovic et al., 2012).

Giagazoglou et al. $(2012,2013)$ examined the effects of different exercise programs on balance in moderate intellectually disabled young people. The first study stated that the hippotherapy intervention program resulted in significant improvements in strength parameters, and on the more complex balance task (Giagazoglou et al., 2012), and the second indicated that the trampoline intervention resulted in significant improvements of participants' performance in all motor and balance tests (Giagazoglou et al., 2012).

Based on the results of previous studies there is the fact that the degree of balance development in children and adolescents with mild ID is low, but it is possible to influence on this motor ability by means of physical activity. The experimental exercise program was designed in such a way that allows practice of the motor skill of balance in each task, although often this is done indirectly. In accordance with the results of studies in which different types of intervention programs were applied, it is clear that it certainly makes sense to continue developing new and better programs of physical activity, to improve the motor skills of children and young people with mild intellectual disability.

\section{CONCLUSION}

Based on the analyses of the obtained results, we can conclude that the applied experimental exercise program was efficient in increasing the motor ability of balance in a group of mild intellectually disabled adolescents. The effects that were identified were primarily a result of the increased physical activation and possibly increased trunk muscle strength that participated in the execution of each task, and are essential for good posture. The most important one is the proper focus of attention of intellectually disabled adolescents when applying any exercise program. Tasks in the form of polygons are extremely interesting for the studied population, so it is further recommended that this kind of work should be applied more often. A similar exercise program could be applied to the younger adolescents and children with mild intellectual disabilities, and its impact on other motor skills could be monitored. 


\section{REFERENCES}

Bernard, S. H. (2011). The mental health needs of children with intellectual disabilities. Mental Health in Intellectual Disabilities: A Reader (4th Ed.), Pavilion.

Blomqvist, S., Wester, A., \& Rehn, B. (2014). Postural muscle responses and adaptations to backward platform perturbations in young people with and without intellectual disability. Gait \& posture, 39(3), 904-908.

Bruininks, R. H., \& Bruininks, B. D. (2010). Bruininks-Oseretsky Test of Motor Proficiency - 2nd Ed. Bot-2, $4(3), 6$.

Buntinx, W. H., \& Schalock, R. L. (2010). Models of disability, quality of life, and individualized supports: Implications for professional practice in intellectual disability. Journal of Policy and Practice in Intellectual Disabilities, 7(4), 283-294.

Giagazoglou, P., Arabatzi, F., Dipla, K., Liga, M., \& Kellis, E. (2012). Effect of a hippotherapy intervention program on static balance and strength in adolescents with intellectual disabilities. Research in developmental disabilities, 33(6), 2265-2270.

Giagazoglou, P., Sidiropoulou, M., Mitsiou, M., Arabatzi, F., \& Kellis, E. (2015). Can balance trampoline training promote motor coordination and balance performance in children with developmental coordination disorder?. Research in developmental disabilities, 36, 13-19.

Golubović, Š., Maksimović, J., Golubović, B., \& Glumbić, N. (2012). Effects of exercise on physical fitness in children with intellectual disability. Research in developmental disabilities, 33(2), 608-614.

Jankowicz-Szymanska, A., Mikolajczyk, E., \& Wojtanowski, W. (2012). The effect of physical training on static balance in young people with intellectual disability. Research in developmental disabilities, 33(2), 675-681.

Maina, G., Albert, U., Bada, A., \& Bogetto, F. (2001). Occurrence and clinical correlates of psychiatric comorbidity in delusional disorder. European psychiatry, 16(4), 222-228.

Pallant, J. (2011). A step by step guide to data analysis using SPSS. Alen \& Unwin.

Radenković, M., Berić, D., \& Kocić, M. (2014). The influence of the elements of basketball on the development of motor skills in children with special needs. Facta Universitatis, Series: Physical Education and Sport, 12(2), 123-130.

Vuijk, P. J., Hartman, E., Scherder, E., \& Visscher, C. (2010). Motor performance of children with mild intellectual disability and borderline intellectual functioning. Journal of intellectual disability research, 54(11), 955-965.

Winnick, J., \& Porretta, D. (2016). Adapted Physical Education and Sport, 6E. Human Kinetics.

\section{UTICAJ EKSPERIMENTALNOG PROGRAMA VEŽBANJA NA RAVNOTEŽU MLADIH SA SMETNJAMA U INTELEKTUALNOM FUNKCIONISANJU}

Cilj ovog istraživanja bio je da se utvrde efekti eksperimentalnog programa vežbanja na ravnotežu adolescenata sa lakim intelektualnim invaliditetom. U studiji je učestvovalo 15 ispitanika uzrasta 15-20 godina, sa lakim smetnjama u intelektualnom funkcionisanju koji pohađaju specijalnu školu „,14. Oktobar" u Nišu. Eksperimentalni program vežbanja trajao je 12 nedelja, dva puta nedeljno po 45 minuta. Program se sastojao od vežbi za razvoj ravnoteže, vežbi snage, različitih igara sa loptom i poligona na košarkaškom terenu sa košarkaškom loptom. Pre početka primene eksperimentalnog programa vežbanja $i$ nakon 12 nedelja primene tog programa testirana je sposobnost ravnoteže pomoću devet zadataka BOT-2. Rezultati ukazuju na to da je primenjeni program vežbanja doprineo statistički značajnom povećanju ukupnog rezultata ravnoteže ( $p=0.002)$, hodanju unaped peta-prsti po liniji $(p=0.045)$, stajanju na jednoj nozi na liniji sa zatvorenim očima $(p=0.027)$ i stajanju na jednoj nozi na klupici za ravnotežu sa zatvorenim očima $(p=0.006)$. Na osnovu dobijenih rezultata može se zaključiti da je primenjeni program vežbanja pozitivno uticao na ravnotežu mladih sa lakim intelektualnim invaliditetom.

Ključne reči: Bruininks-Oseretsky Test, Motoričke sposobnosti, fizičko vaspitanje 